\title{
Effect of Oxidation Temperature on Photo-catalytic Properties of Stainless Steel Coated by Copper Oxide
}

\author{
Motoaki MORITA, ${ }^{1) *}$ Kengo KISHIHARA, ${ }^{1)}$ Shinichi MOTODA, ${ }^{1)}$ Norimitsu KOGA ${ }^{2)}$ and Tadashi SHINOHARA ${ }^{3)}$ \\ 1) Tokyo University of Marine Science and Technology, 2-1-6 Etujima, Koto-Ku, Tokyo, 135-8533 Japan. \\ 2) Yokohama National University, 79-5 Tokiwadai, Hodogaya-Ku, Yokohama, 240-8501 Japan. \\ 3) National Institute for Materials Science, 1-2-1 Sengen, Tsukuba-shi, Ibaraki, 305-0047 Japan.
}

(Received on February 13, 2017; accepted on April 27, 2017)

\begin{abstract}
Copper oxide (Cu-oxide) electrodes were produced by the vacuum deposition of pure copper on a stainless steel substrate, followed by oxidation in air between 150 and $550^{\circ} \mathrm{C}$. The potentials and durability of the $\mathrm{Cu}$-oxide electrodes under xenon light irradiation were evaluated, and the effects of the microstructure on the electrode performance were discussed. The photocatalytic effect of a p-type semiconductor in a $\mathrm{Cu}$-oxide electrode was confirmed for all treatment temperatures. Electrodes oxidized at $150^{\circ} \mathrm{C}$ showed a very weak photocatalytic effect because the main phase of the thin film comprised amorphous $\mathrm{Cu}$. The potentials of the electrodes oxidized at 450 and $550^{\circ} \mathrm{C}$ shifted to more than $230 \mathrm{mV}$ (SCE) after light irradiation but they immediately decreased to $100 \mathrm{mV}$ (SCE) due to the self-corrosion (photo-corrosion) of $\mathrm{CuO}$. The electrodes oxidized at 250 and $350^{\circ} \mathrm{C}$ retained their photocatalytic activities at irradiation time of more than $24 \mathrm{~h}$. The initial potentials of the electrodes oxidized at 250 and $350^{\circ} \mathrm{C}$ are $100 \mathrm{mV}$ (SCE) and $280 \mathrm{mV}$ (SCE), respectively. The potential of the electrode oxidized at $250^{\circ} \mathrm{C}$ increased with time because $\mathrm{Cu}_{2} \mathrm{O}$, which was the initial main phase of the electrode, was oxidized to $\mathrm{CuO}$ by a surface reaction during irradiation. In the electrode oxidized at $350^{\circ} \mathrm{C}$, the photo-excited electrons and the photo-generated holes hardly reacted with the electrode surface by the interactions between the Cu-oxide film and the passive film of stainless steel substrate. The electrode exhibited the best performance in terms of potential and durability during the light irradiation.
\end{abstract}

KEY WORDS: photocathode; photo-corrosion; cuprous oxide; cupric oxide; p-p junction; passive film.

\section{Introduction}

Wet solar cells using seawater as an electrolyte have been reported as a method to generate solar power directly using marine environments. ${ }^{1-4)}$ The advantage of generating power in this manner is that using seawater as an electrolyte means that the cell walls are not required to contain the electrolyte, and thus the vast area of the ocean may be utilized. However, it is unrealistic to use expensive electrode materials over such large areas; therefore, low-cost, high-performance electrode materials are needed. A great deal of research and development has been performed using titanium dioxide $\left(\mathrm{TiO}_{2}\right)$ as a photocatalytic anode with the above characteristics. ${ }^{4}$ However, there are not many studies of the cathodes that constitute these cells. For example, stainless steel is superior in cost effectiveness and corrosion resistance as a cathode electrode, but it is not often used because of its low catalytic activity. One effective utilization of a stainless steel in electrodes is to use it as substrate on which a p-type semiconductor is deposited. The metal oxides used in p-type semiconductors include copper (I, II) oxide $\left(\mathrm{Cu}_{2} \mathrm{O}\right.$ and $\left.\mathrm{CuO}\right)$, nickel (II) oxide (NiO), and

\footnotetext{
* Corresponding author: E-mail: morita@kaiyodai.ac.jp DOI: http://dx.doi.org/10.2355/isijinternational.ISIJINT-2017-087
}

cobalt (II) oxide (CoO). In particular, $\mathrm{Cu}_{2} \mathrm{O}$ and $\mathrm{CuO}$ are easy to obtain and can produce a layer. For example, the high-temperature oxidation of a pure $\mathrm{Cu}$ film can produce an oxide film with photocatalytic activity at a low cost. In previous studies, the electrical properties and photoelectrical ones of the oxide film on a glass and $\mathrm{Cu}$ sheet have been reported. ${ }^{5-8)}$ However, the relationship between photopotential and durability of the oxide film is not apparent. In addition, there are few works to report the effect of a substrate on the property of the electrode. In this study, the cathode electrode was produced by the high-temperature oxidation of a pure $\mathrm{Cu}$ film that was vacuum vapor-deposited onto stainless steel substrate, and the electrode potential of their electrodes were measured. We elucidated the effect of the oxidation temperature on the photopotential and durability of the $\mathrm{Cu}$-oxide formed on the stainless steel substrate applying to the cathode electrode of the cells.

\section{Experimental Method}

\subsection{Preparation of $\mathrm{Cu}$-oxide Electrodes}

2.1.1. Formation of the Vapor-deposited Film

We used Type 329J4L dual-phase stainless steel as the substrate and \#40 sandpaper to grind a grid pattern into the substrate. The chemical composition of the Type 329J4L 
Table 1. Chemical composition of Type 329J4L stainless steel substrate (mass\%).

\begin{tabular}{ccccccccccccc}
\hline \multirow{2}{*}{ Type 329J4L } & $\mathrm{C}$ & $\mathrm{Si}$ & $\mathrm{Mn}$ & $\mathrm{P}$ & $\mathrm{S}$ & $\mathrm{Ni}$ & $\mathrm{Cr}$ & $\mathrm{Mo}$ & $\mathrm{W}$ & $\mathrm{N}$ \\
\cline { 2 - 28 } & 0.025 & 0.44 & 0.77 & 0.027 & - & 6.34 & 24.96 & 3.22 & 0.14 & 0.27 \\
\hline
\end{tabular}

stainless steel is shown in Table 1. Pure $\mathrm{Cu}$ was vacuum vapor-deposited onto the stainless steel substrate under the following conditions: vacuum $=0.4 \times 10^{-3} \mathrm{~Pa}$, current $=40 \mathrm{~A}$, and voltage $=1.3 \mathrm{~V}$. The thickness of the vapor-deposited $\mathrm{Cu}$ film was about $0.3 \mu \mathrm{m}$.

\subsubsection{Oxidation Treatment of the Vapor-deposited Film}

A heat treatment was performed in open air using a muffle furnace, and then the vapor-deposited pure $\mathrm{Cu}$ film was oxidized. The heat treatment was performed at temperatures of $150,250,350,450$, and $550^{\circ} \mathrm{C}$. The temperatures were maintained for intervals of $30 \mathrm{~min}$, and then samples were air-cooled. These electrodes are referred to as $\mathrm{Cu}$-oxide electrodes.

\subsection{Irradiation Testing to Measure the Photopotential}

Figure $\mathbf{1}$ is a schematic diagram of a photopotential measuring device. A saturated calomel electrode (SCE) was used as the reference electrode (RE), and the working electrode (WE) was a Cu-oxide electrode. We use the abbreviated unit of $\mathrm{mV}$ to represent the potential with respect to the SCE $(\mathrm{mV}(\mathrm{SCE}))$. Artificial seawater was used as the electrolyte in this cell module. To prevent a change of the refractive index from affecting the electrode properties, the vertical incident light on the electrode surface initially passed through a quartz glass window. The distance between sample and the quartz glass is $3 \mathrm{~mm}$. The standard light source was a $150 \mathrm{~W}$ xenon lamp with a wavelength range of 250 to $800 \mathrm{~nm}$, and the intensity of the light exiting the quartz glass window was $105 \mathrm{~W} / \mathrm{m}^{2}$. The electrode was kept in dark conditions for three min in the artificial seawater, irradiated with the xenon lamp, and then the potential was measured for $24 \mathrm{~h}$.

\subsection{Microstructure of the Oxidized Vapor-deposited Film}

The electrode surface was examined using images from an optical camera. In addition, we used a scanning electron microscope (SEM)/energy-dispersive X-ray spectroscopy (EDS) to analyze the microstructure of the $\mathrm{Cu}$-oxide electrode surfaces. The phases of the main components of the vapor-deposited film were identified using an X-ray diffraction (XRD) apparatus.

\section{Results and Discussion}

\subsection{Photocatalytic Properties of the Electrodes}

Figure 2(a) shows the changes of the electrode potential before and after light irradiation in the $24 \mathrm{~h}$ irradiation testing. For all the electrodes, the potential ennobled immediately after light irradiation. Especially, the $\mathrm{Cu}$-oxide electrodes with the oxidation temperatures between $350^{\circ} \mathrm{C}$ and $550^{\circ} \mathrm{C}$ rapidly ennobled. The ennobled potentials of the electrodes with oxidation temperatures above $250^{\circ} \mathrm{C}$ were $100 \mathrm{mV}$ or higher after light irradiation compared to

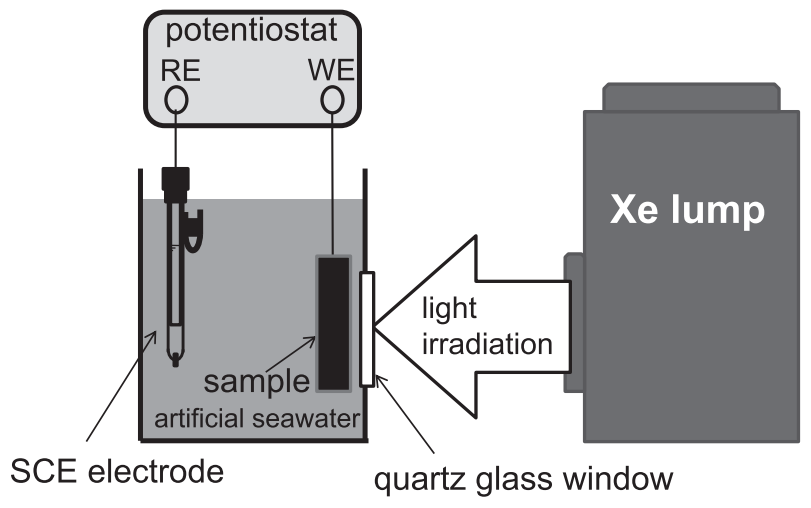

Fig. 1. Schematic representation of the experimental apparatus for measuring the electrode potential.
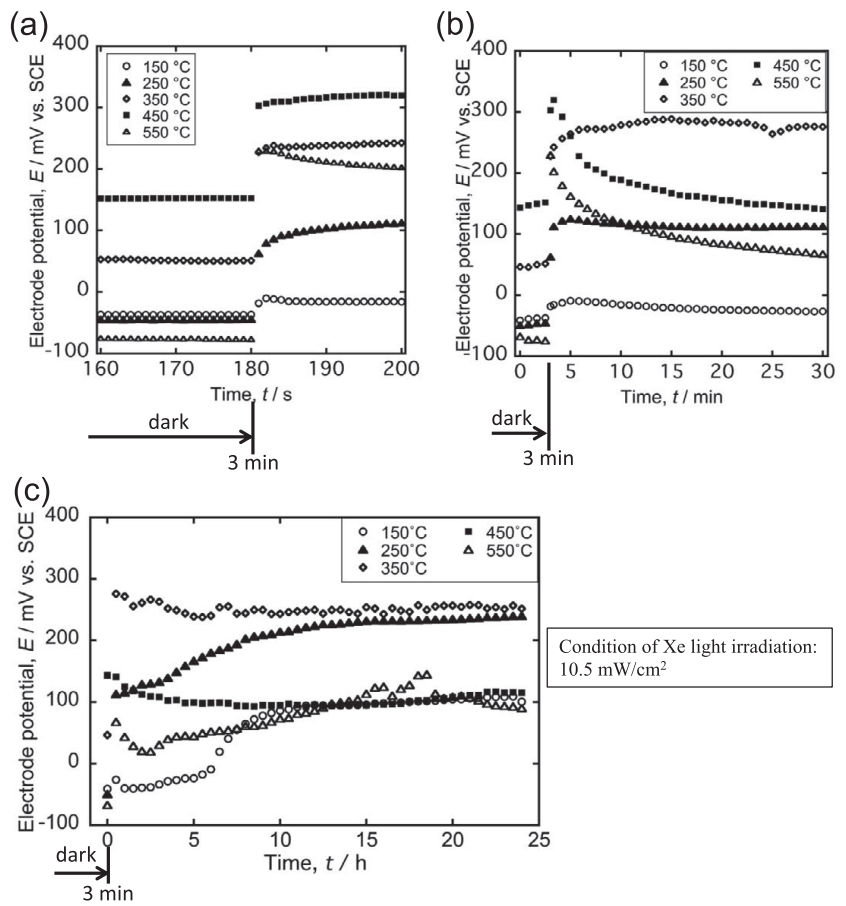

Fig. 2. Time variation of the electrode potentials for the electrodes which are oxidized at $150,250,350,450$, and $550^{\circ} \mathrm{C}$ (a) before and after light irradiation, and during (b) the first $30 \mathrm{~min}$ and (c) $24 \mathrm{~h}$ in the $24 \mathrm{~h}$ irradiation testing.

the value in the dark. The potential immediately after light irradiation tended to be more ennobled for electrodes treated at higher oxidation temperatures.

The potentials of the electrodes treated at the oxidation temperatures of 150,250 , and $350^{\circ} \mathrm{C}$ stabilized within $30 \mathrm{~min}$ of irradiation (Fig. 2(b)), and their values after $30 \mathrm{~min}$ were $-30,120$, and $280 \mathrm{mV}$, respectively. The electrode potentials with the oxidation temperatures of 450 and $550^{\circ} \mathrm{C}$ decreased with time during the 30 min irradiation. For each electrode, the potential at an irradiation time of $24 \mathrm{~h}$ was different from that at $30 \mathrm{~min}$ (Fig. 2(c)). The potential of the electrodes with an oxidation temperature 

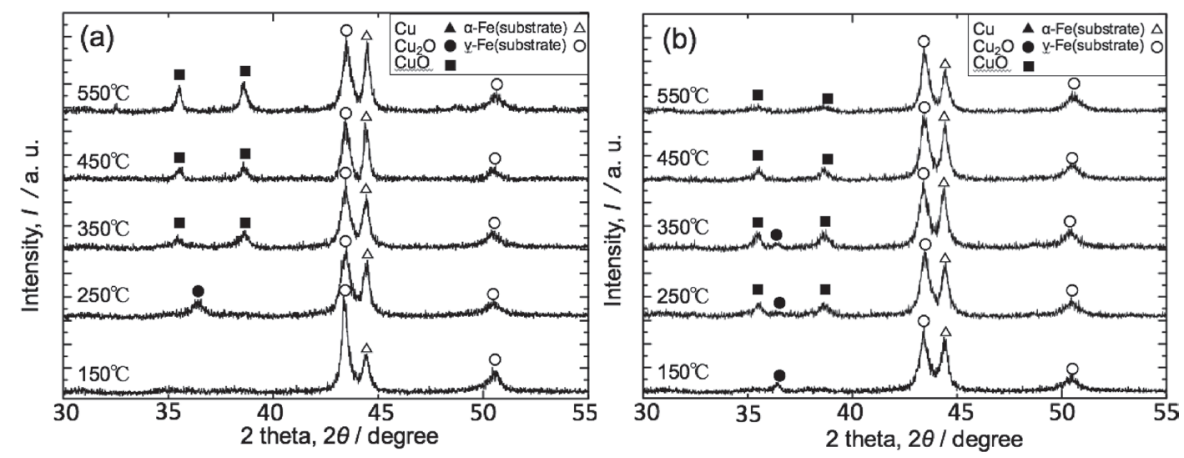

Fig. 3. X-ray diffraction profiles of the oxidized electrodes (a) before and (b) after the $24 \mathrm{~h}$ of Xe light irradiation.

of $150^{\circ} \mathrm{C}$ showed a significant ennoblement after $5 \mathrm{~h}$, and stabilized at $100 \mathrm{mV}$ after $12 \mathrm{~h}$. The potential of the electrodes with an oxidation temperature of $250^{\circ} \mathrm{C}$ ennobled significantly up to $15 \mathrm{~h}$, and the trend continued to a lesser degree, reaching $230 \mathrm{mV}$ at $24 \mathrm{~h}$. The photopotential of the electrodes oxidized at $350^{\circ} \mathrm{C}$ gradually decreased up to an irradiation time of $6 \mathrm{~h}$, and then gradually became ennobled. The potential at $24 \mathrm{~h}$ was $260 \mathrm{mV}$. The potential of the electrodes with an oxidation temperature of $450^{\circ} \mathrm{C}$ continued to decrease following light irradiation, reaching $110 \mathrm{mV}$ after $24 \mathrm{~h}$. The potential of the electrodes with an oxidation temperature of $550^{\circ} \mathrm{C}$ decreased significantly initially, but started to ennoble after $30 \mathrm{~min}$. The potential at $24 \mathrm{~h}$ was about $90 \mathrm{mV}$. The potentials of the electrodes with oxidation temperatures of 250 and $350^{\circ} \mathrm{C}$ were $200 \mathrm{mV}$ or higher, and those with oxidation temperatures of 150,450 , and $550^{\circ} \mathrm{C}$ were about $100 \mathrm{mV}$.

\subsection{Time Variations of the Microstructures in the Elec- trodes}

3.2.1. Phase Identification of the Electrodes Prior to the Irradiation Test

Figure 3(a) shows the XRD profile of each electrode prior to the test. For all the electrodes, both ferrite phase $(\alpha-\mathrm{Fe})$ diffraction peaks and austenitic phase $(\gamma-\mathrm{Fe})$ ones were detected. The stainless steel substrate (Type 329J4L) is comprised with their phases, and X-ray was transmitted through to the substrate. The diffraction peaks of austenitic phase in Type 329J4L are almost the same with those of crystalline $\mathrm{Cu}$. In this study, the diffraction peaks of the $\mathrm{Cu}$-oxide electrode with all the same temperatures at ferrite stainless steel (Type 430) were also measured, and their results ensured no crystalline $\mathrm{Cu}$ in the $\mathrm{Cu}$-oxide film before light irradiation. The diffraction peak of $\mathrm{Cu}_{2} \mathrm{O}$ was observed for the electrodes oxidized at $250^{\circ} \mathrm{C}$. The diffraction peaks of $\mathrm{CuO}$, was detected for the electrodes with oxidation temperatures of 350,450 , and $550^{\circ} \mathrm{C}$. At an oxidation temperature of $150^{\circ} \mathrm{C}$, the diffraction peaks of the $\mathrm{Cu}$ species (such as pure $\mathrm{Cu}, \mathrm{Cu}_{2} \mathrm{O}$, and $\mathrm{CuO}$ ) were not detected. The $\mathrm{XRD}$ results for the substrate, as-vapor-deposited material, and the material heat-treated at $250^{\circ} \mathrm{C}$ are shown in Fig. 4. In earlier studies, amorphous films were sometimes observed when metal films were formed through vacuum vapor-deposition, ${ }^{9,10)}$ and sometimes the XRD profile background values would increase. ${ }^{11)}$ Pure $\mathrm{Cu}$ diffraction peak was not observed in the as-vapor-deposited material, but its background intensity was higher than that for the substrate.

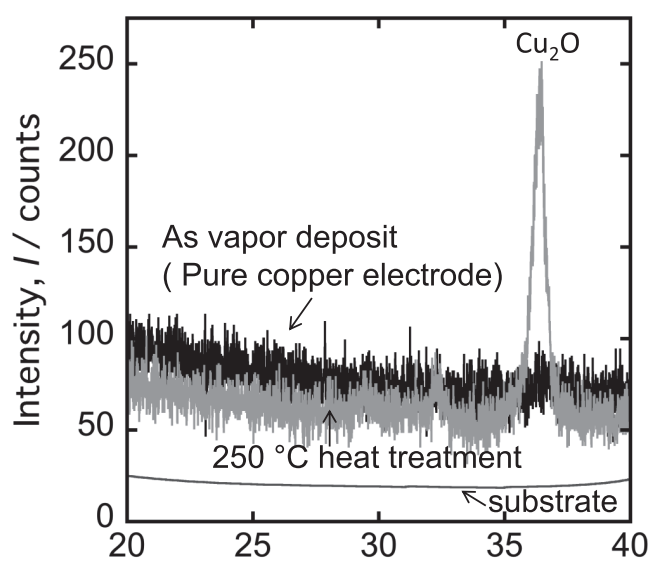

Fig. 4. X-ray diffraction profiles of the Type 329J4L stainless steel substrate, the as-vapor-deposited electrode, and its oxidized one at $250^{\circ} \mathrm{C}$.

Therefore, the as-vapor-deposited pure $\mathrm{Cu}$ was amorphous, and the main component of the surface film treated at an oxidation temperature of $150^{\circ} \mathrm{C}$ was amorphous $\mathrm{Cu}$. The background intensity for the electrodes with an oxidation temperature of $250^{\circ} \mathrm{C}$ was lower than that of the asdeposited material, and showed a clear diffraction peak of $\mathrm{Cu}_{2} \mathrm{O}$. Therefore, the heat treatment at $250^{\circ} \mathrm{C}$ oxidized the amorphous $\mathrm{Cu}$ on the electrode to $\mathrm{Cu}_{2} \mathrm{O}$. The background values in all the heat-treated electrodes were higher than that of the untreated substrate, and thus, it is likely that the non-oxidized amorphous $\mathrm{Cu}$ remained in the film on all $\mathrm{Cu}$-oxide electrodes.

The main phase that constitutes the vapor-deposited film on the electrodes with an oxidation temperature of $150^{\circ} \mathrm{C}$ was amorphous $\mathrm{Cu}$, that on the electrodes with an oxidation temperature $250^{\circ} \mathrm{C}$ was $\mathrm{Cu}_{2} \mathrm{O}$, while those of 350,450 , and $550^{\circ} \mathrm{C}$ were $\mathrm{CuO}$.

\subsubsection{Effect of the Surface Microstructure on the Photoca- talysis under Light Irradiation}

The electrodes produced at an oxidation temperature of $150^{\circ} \mathrm{C}$ exhibited no remarkable ennoblement after light irradiation (Fig. 2(a)). The vapor-deposited pure copper film did not become oxidized at this temperature. A significant photocatalytic effect was not expected because the main component was amorphous $\mathrm{Cu}$. Electrodes with oxidation temperatures of $250^{\circ} \mathrm{C}$ or higher became clearly ennobled after light irradiation. The potential of the electrodes with an oxidation temperature of $250^{\circ} \mathrm{C}$ was $100 \mathrm{mV}$ immediately 


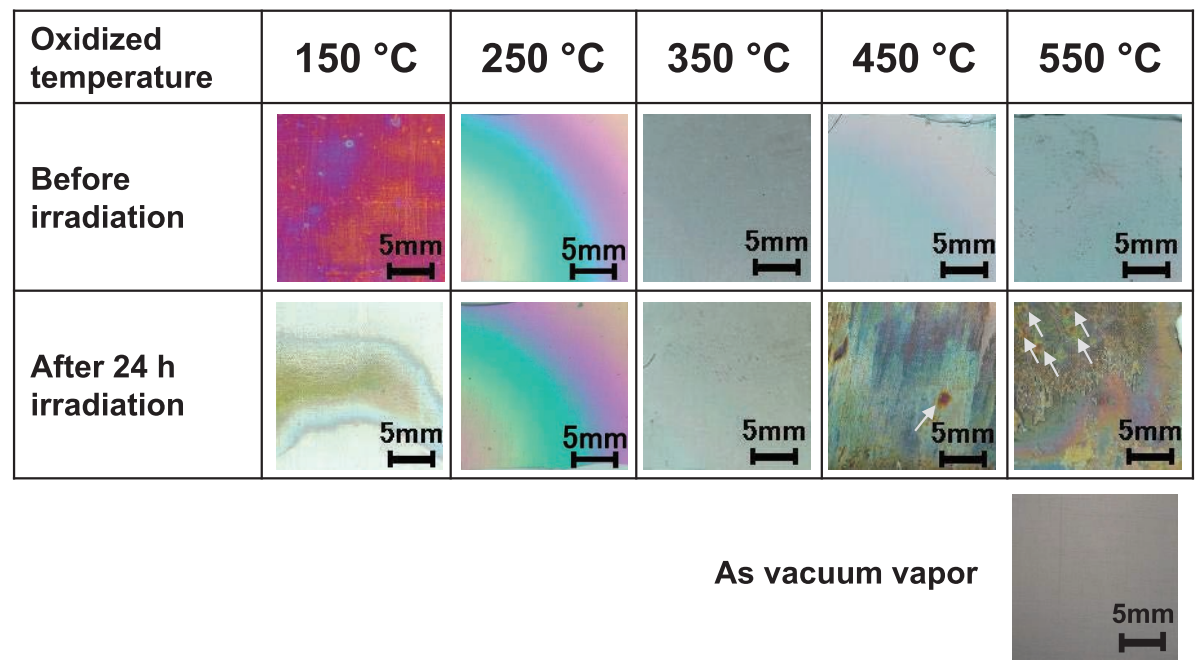

Fig. 5. Optical images of the $\mathrm{Cu}$-oxide electrode surfaces before and after the $24 \mathrm{~h}$ irradiation testing. Arrows show the visually observed pits.

after light irradiation. The potentials of the electrodes with oxidation temperatures of 350,450 , and $550^{\circ} \mathrm{C}$ were around $200 \mathrm{mV}$, higher than that of the electrode oxidized at $250^{\circ} \mathrm{C}$. The main component of the electrodes with oxidation temperatures of $250^{\circ} \mathrm{C}$ was $\mathrm{Cu}_{2} \mathrm{O}$, those of $350^{\circ} \mathrm{C}$ and higher were $\mathrm{CuO}$ (Fig. 3(a)). The electrode potentials immediately after light irradiation correlated with the microstructures of the electrodes.

\subsubsection{Changes of the Electrode Surface Morphology}

Figure 5 shows optical images of the various electrode surfaces before and after the $24 \mathrm{~h}$ irradiation testing. The electrodes with an oxidation temperature of $150^{\circ} \mathrm{C}$ appeared red. $\mathrm{Cu}_{2} \mathrm{O}$ peaks and $\mathrm{CuO}$ ones were not detected in the XRD analysis (Fig. 3(a)). A small amount of copper oxide substance may exist in the film because the electrode had a slight photocatalytic effect (Fig. 2(a)). The surfaces of the electrodes with oxidation temperatures of $250,350,450$, and $550^{\circ} \mathrm{C}$ presented the interference color, especially at $250^{\circ} \mathrm{C}$. The interference colors of the electrodes with oxidation temperatures of 350,450 , and $550^{\circ} \mathrm{C}$ contained a black tinge.

After $24 \mathrm{~h}$ irradiation testing, there was a slight visible surface change for the electrodes with oxidation temperatures of 250 and $350^{\circ} \mathrm{C}$; however, there was a significant change in those oxidized at 150,450 , and $550^{\circ} \mathrm{C}$. Some metallic luster was observed on the surface treated at $150^{\circ} \mathrm{C}$, while those treated at 450 and $550^{\circ} \mathrm{C}$ presented an interference color with reddish brown spots.

Figure 6 shows the secondary electron (SE) images of the electrode surfaces before the $24 \mathrm{~h}$ irradiation testing. There were grains whose sizes increased with increasing oxidation temperature. The approximate grains sizes on the electrode surfaces with oxidation temperatures of 150, 250-450, and $500^{\circ} \mathrm{C}$ were $10,30-40$, and $100 \mathrm{~nm}$, respectively. The electrode surfaces with oxidation temperatures of 350,450 , and $550^{\circ} \mathrm{C}$ were porous with a significant surface relief. The surface conditions of the $\mathrm{Cu}$-oxide electrodes after an irradiation time of $24 \mathrm{~h}$ are shown in Fig. 7. The grains disappeared for the electrodes with oxidation temperatures of 150,450 , and $550^{\circ} \mathrm{C}$; the corresponding surface morphology also significantly changed. On the electrode surfaces
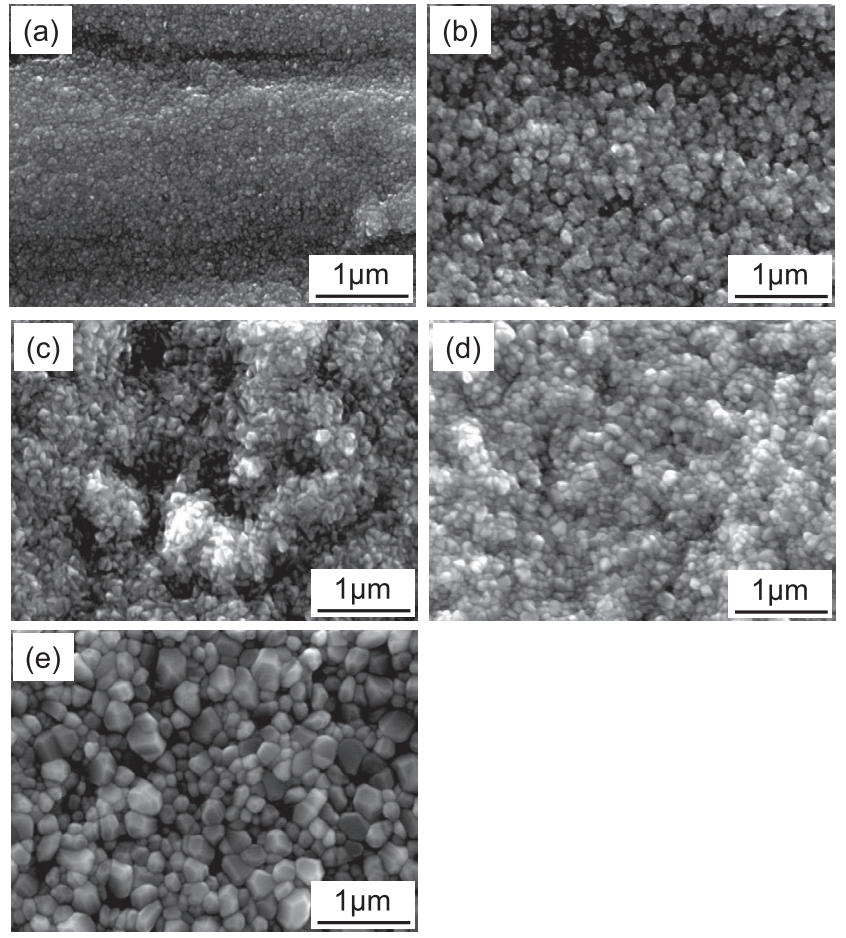

Fig. 6. Secondary electron images of the $\mathrm{Cu}$-oxide electrode surfaces at (a) $150^{\circ} \mathrm{C}$, (b) $250^{\circ} \mathrm{C}$, (c) $350^{\circ} \mathrm{C}$, (d) $450^{\circ} \mathrm{C}$, and (e) $550^{\circ} \mathrm{C}$ before the $24 \mathrm{~h}$ irradiation testing.

oxidized at 250 and $350^{\circ} \mathrm{C}$, there was a slight change of the microstructural surface itself. These results are consistent with the observations from the optical images (Fig. 5). We will discuss the factors associated with these time variations in the following section.

\subsection{Factors Associated with Time Variations of the Electrode Potential}

3.3.1. Electrodes with an Oxidation Temperature of $150^{\circ} \mathrm{C}$

The potential of the electrodes with an oxidation temperature of $150^{\circ} \mathrm{C}$ for the $24 \mathrm{~h}$ irradiation was $100 \mathrm{mV}$, which was also the free corrosion potential of the Type 329J4L stainless steel. After the $24 \mathrm{~h}$ irradiation testing, there was a metallic luster on the surface of the electrodes (Fig. 5). 

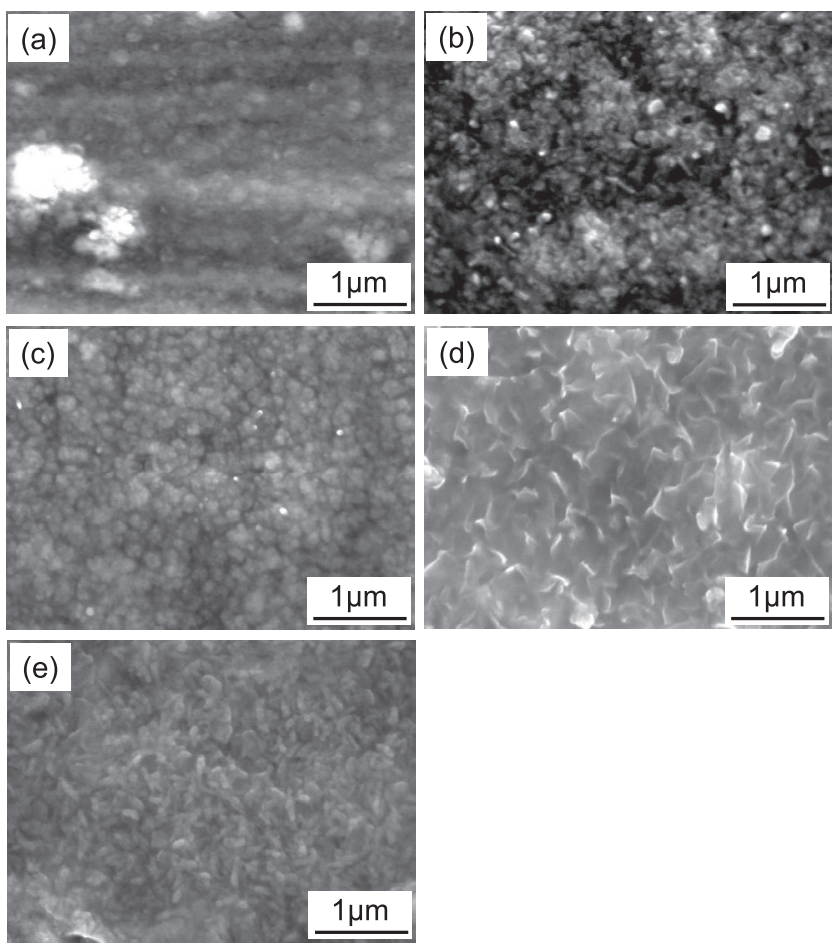

Fig. 7. Secondary electron images of the $\mathrm{Cu}$-oxide electrode surfaces at (a) $150^{\circ} \mathrm{C}$, (b) $250^{\circ} \mathrm{C}$, (c) $350^{\circ} \mathrm{C}$, (d) $450^{\circ} \mathrm{C}$, and (e) $550^{\circ} \mathrm{C}$ after the $24 \mathrm{~h}$ irradiation testing.
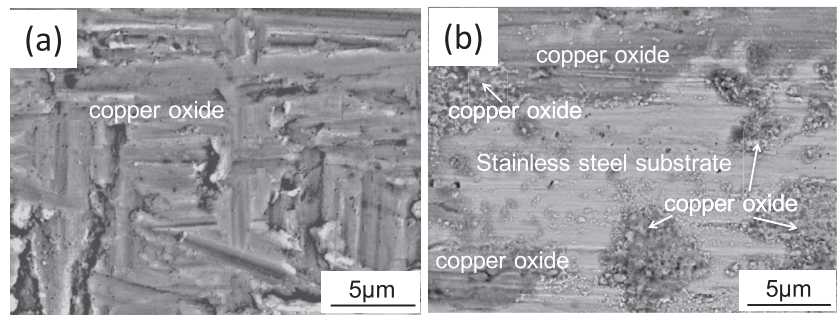

Fig. 8. Backscattered images of the electrodes oxidized at $150^{\circ} \mathrm{C}$ (a) before and (b) after the $24 \mathrm{~h}$ irradiation testing.

We analyzed the area with the metallic luster using SEM/ EDS and confirmed the exposure of stainless steel substrate (Fig. 8). The vapor-deposited film on the electrodes dissolved after the $24 \mathrm{~h}$ irradiation. In addition, the results of the XRD analysis of the electrodes after testing showed a $\mathrm{Cu}_{2} \mathrm{O}$ peak (Fig. 3(b)). $\mathrm{Cu}_{2} \mathrm{O}$ is formed by the corrosion of $\mathrm{Cu}^{12)}$ Therefore, the potential ennoblement of the electrodes with an oxidation temperature of $150^{\circ} \mathrm{C}$ occurred with time due to the corrosion of amorphous $\mathrm{Cu}$ that exposed the stainless steel substrate (whose potential was presented). In galvanic series in seawater, the electrode potential for a stainless steel is more noble than that for $\mathrm{Cu},{ }^{13)}$ and $\mathrm{Cu}$ had a lower potential than stainless steel. Amorphous $\mathrm{Cu}$ might have dissolved during the test due to bimetallic corrosion with the Type 329J4L stainless steel substrate.

\subsubsection{Electrodes with an Oxidation Temperature of $250^{\circ} \mathrm{C}$}

The potential of the electrodes with an oxidation temperature of $250^{\circ} \mathrm{C}$ was $100 \mathrm{mV}$ immediately after light irradiation, and it was ennobled up to $200 \mathrm{mV}$ during the $24 \mathrm{~h}$ irradiation (Fig. 2). There was no significant difference of the surface microstructure before or after the irradiation test (Fig. 5), although the main component of the electrode

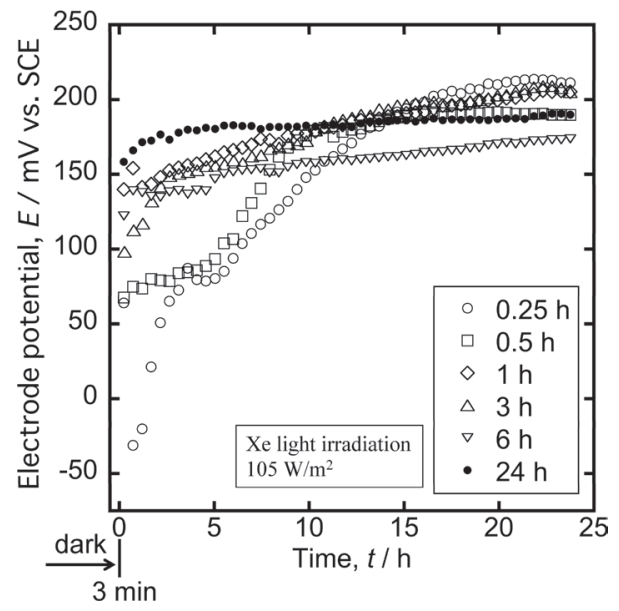

Fig. 9. Time variation of the electrode potentials for the $\mathrm{Cu}$-oxide electrodes oxidized at $250^{\circ} \mathrm{C}$ for $15 \mathrm{~min}, 30 \mathrm{~min}, 1 \mathrm{~h}, 3 \mathrm{~h}, 6$ $\mathrm{h}$, and $24 \mathrm{~h}$.

surfaces changed from $\mathrm{Cu}_{2} \mathrm{O}$ to $\mathrm{CuO}$ (Fig. 3(b)). Therefore, after the $24 \mathrm{~h}$ irradiation, the potential of $230 \mathrm{mV}$ was caused by the photocatalytic effect of $\mathrm{CuO}$. In these electrodes, the main component $\left(\mathrm{Cu}_{2} \mathrm{O}\right)$ was oxidized to $\mathrm{CuO}$, ennobling the electrode potential. To verify this phenomenon, we prepared electrodes with accelerated oxidation from $\mathrm{Cu}_{2} \mathrm{O}$ to $\mathrm{CuO}$ by controlling heat treatment time, and evaluated the time variations of their electrode potentials (Fig. 9). The potentials of the electrodes that were heat-treated for $\geq 1$ hour were ennobled to about $150 \mathrm{mV}$ immediately after light irradiation, while those of electrodes with $\leq 30$ min of heat treatment was lower. However, the potentials of the latter electrodes became more ennobled with time; after the irradiation time of $12 \mathrm{~h}$, the potentials became similar to that of the electrode heat-treated for $1 \mathrm{~h}$. The ennobling of the potential up to $12 \mathrm{~h}$ was caused by the photocatalytic effect of $\mathrm{Cu}_{2} \mathrm{O}$ or $\mathrm{CuO}$.

\subsubsection{Electrodes with an Oxidation Temperature of $350^{\circ} \mathrm{C}$}

The potential of the electrodes with oxidation temperatures of $350^{\circ} \mathrm{C}$ decreased with time up to $12 \mathrm{~h}$, and then stabilized (Fig. 2(c)). No change was observed in the optical images of the electrode surfaces (Fig. 5), and the grains appeared to have dissolved (Figs. 6 and 7). The XRD profile of the electrode after the $24 \mathrm{~h}$ irradiation testing showed $\mathrm{CuO}$ and $\mathrm{Cu}_{2} \mathrm{O}$ peaks (Fig. 3). It seemed that the amorphous $\mathrm{Cu}$ in the deposited film was corroded, and $\mathrm{Cu}_{2} \mathrm{O}$ was formed during the $24 \mathrm{~h}$ irradiation.

\subsubsection{Electrodes with Oxidation Temperatures of 450 and $550^{\circ} \mathrm{C}$}

Grains found prior to the $24 \mathrm{~h}$ irradiation testing were no longer observed on the surfaces of the electrodes at oxidation temperatures of 450 and $550^{\circ} \mathrm{C}$ after the $24 \mathrm{~h}$ irradiation (Figs. 6 and 7). Immediately after light irradiation, the potential rapidly ennobled to $200 \mathrm{mV}$ and higher, but then rapidly decreased. It appears that the photocorroded due to its own photocatalytic effect. We analyzed the pits area shown in Fig. 5. A clear contrast was observed in the BSE image near the pits, and SEM/EDS analysis confirmed that the iron concentration. The pits in the optical images was the pitting corrosion of stainless steel substrate. When the 


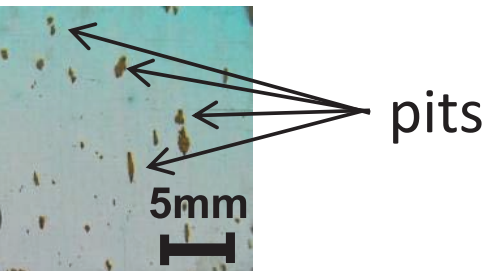

Fig. 10. Optical image of the surface on the $\mathrm{Cu}$-oxide electrode with the oxidation temperature of $550^{\circ} \mathrm{C}$ after the $24 \mathrm{~h}$ non-irradiation testing. Arrows show some observed pits.

electrodes immersed under the condition of non-irradiation, only the pitting of stainless steel occurred (Fig. 10). Therefore, $\mathrm{CuO}$ results from the photocorrosion under the light irradiation, while the pitting may result from the structural defects of oxide film formed on the electrode with the oxidation temperature of 450 and $550^{\circ} \mathrm{C}$.

\subsection{Optical Responsivity}

The electrodes with an oxidation temperature of $350^{\circ} \mathrm{C}$ had a more ennobled potential and were more stable than the other heat-treated electrodes (Fig. 2(c)). They also showed little change in the surface microstructure before and after the $24 \mathrm{~h}$ irradiation testing and had a higher durability (Figs. 5-7). Therefore, they demonstrated the best performance in terms of the potential and durability among the prepared electrodes. The $72 \mathrm{~h}$ irradiation testing was performed using these optimal electrodes, and the results are shown in Fig. 11(a). Ennobling continued from $12 \mathrm{~h}$ until the end of testing, and the potential reached $280 \mathrm{mV}$. There was no significant change in the electrode surface morphology before or after the $24 \mathrm{~h}$ irradiation test. We also alternated the irradiation and darkness every hour using the present electrodes, and evaluated their photocatalytic effect and optical responsivity (Fig. 11(b)). The potential ennobled immediately upon light irradiation; within $10 \mathrm{~min}$ of light exposure, it reached a maximum value that was higher than that of the same electrode immersed for $72 \mathrm{~h}$. The ennobled potential decreased with time, reaching the pre-irradiation value within $1 \mathrm{~h}$ of the light cut-off, although the photocatalytic effect was still observed at this point. The potential of the electrode prepared at an oxidation temperature $350^{\circ} \mathrm{C}$ followed the same pattern as that of the light irradiation.

\subsection{Semiconductor Properties of the Passive Film Formed on Type 329J4L Stainless Steel}

The time variation of the electrode potentials of the stainless steel substrates varying the oxidation temperatures between 150 and $550^{\circ} \mathrm{C}$ were measured (Fig. 12). Immediately after light irradiation, the substrates with the oxidation temperatures between 150 and $350^{\circ} \mathrm{C}$ exhibited the n-type semiconductor property, while those with the oxidation temperatures of 450 and $550^{\circ} \mathrm{C}$ exhibited p-type semiconductor property. The oxide state was identified by XPS analysis. The main oxides of passive film on Type 329J4L were iron oxide and chromium oxide. Figure 13 shows XPS Spectra of Fe $2 p_{3 / 2}$ and $\mathrm{Cr} 2 \mathrm{p}_{3 / 2}$ on Type 329J4L with the oxidation temperatures of 250 and $550^{\circ} \mathrm{C}$. When the oxidation temperature increased, the amount of iron oxide decreased and that of chromium oxide increased. After background subtraction, the XPS results were separated into contribu- (a)

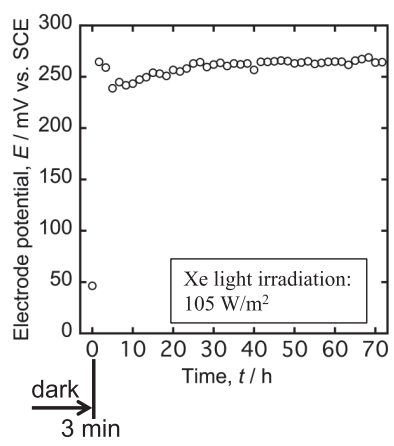

(b)

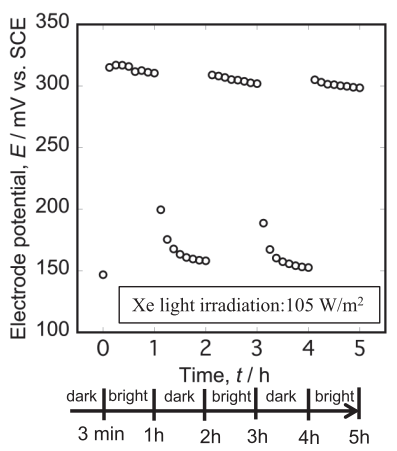

Fig. 11. Time variation of the potential of the electrodes oxidized at $350^{\circ} \mathrm{C}$ for $72 \mathrm{~h}(\mathrm{a})$, and on-off photoresponsivity of the electrode potential after $72 \mathrm{~h}$ of irradiation (b).

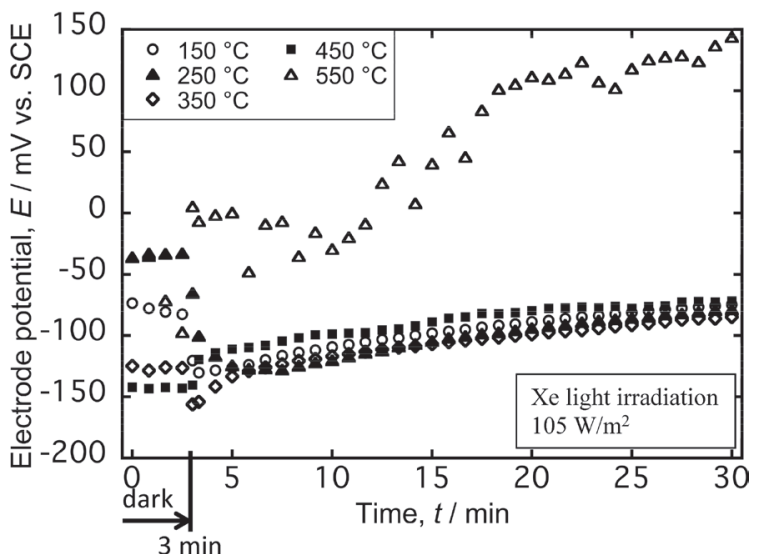

Fig. 12. Time variation of electrode potentials of the stainless steel substrates oxidized at $150,250,350,450$, and $550^{\circ} \mathrm{C}$ during $30 \mathrm{~min}$.

tions of the different oxidation states by referring the XPS spectra of the oxides and hydroxides of iron ${ }^{14-21)}$ and chronium. ${ }^{21-27)}$ The most amount of oxide at the electrode with the oxidation temperature of $250^{\circ} \mathrm{C}$ and $550^{\circ} \mathrm{C}$ was $\mathrm{Fe}_{3} \mathrm{O}_{4}$ and $\mathrm{Cr}_{2} \mathrm{O}_{3}$, respectively. The main oxides of passive film in the austenitic stainless steel (Type 304) with the oxidation temperature at $350^{\circ} \mathrm{C}^{28)}$ are $\mathrm{Fe}_{2} \mathrm{O}_{3}$ and $\mathrm{Cr}_{2} \mathrm{O}_{3}$, and it agrees with those of passive film formed on type $329 \mathrm{~J} 4 \mathrm{~L}$. $\mathrm{Fe}_{2} \mathrm{O}_{3}$ is n-type semiconductor ${ }^{28,29)}$ and $\mathrm{Cr}_{2} \mathrm{O}_{3}$ is p-type one. ${ }^{28,30)}$ The types of semiconductor depend on the main oxide of the passive film. Therefore, the main oxides of the passive films with the oxidation temperatures between 150 and $350^{\circ} \mathrm{C}$ are $\mathrm{Fe}_{2} \mathrm{O}_{3}$, and those with the oxidation temperatures of 450 and $550^{\circ} \mathrm{C}$ are $\mathrm{Cr}_{2} \mathrm{O}_{3}$.

\subsection{Surface Reactions of the Electrode during Light Irradiation}

The surface reactions of $\mathrm{Cu}_{2} \mathrm{O}$ semiconductor in aqueous $^{31)}$ can be expressed as

$$
\begin{aligned}
& \mathrm{Cu}_{2} \mathrm{O}+\mathrm{H}_{2} \mathrm{O}+2 \mathrm{e}^{-} \rightarrow 2 \mathrm{Cu}+2 \mathrm{OH}^{-} \\
& \mathrm{Cu}_{2} \mathrm{O}+\mathrm{H}_{2} \mathrm{O}+2 \mathrm{~h}^{+} \rightarrow 2 \mathrm{CuO}+2 \mathrm{H}^{+}
\end{aligned}
$$

In general p-type $\mathrm{Cu}_{2} \mathrm{O}$ /substrate electrodes in aqueous, the photo-excited electrons reduce $\mathrm{Cu}_{2} \mathrm{O}$ to $\mathrm{Cu}^{32)}$ In the $\mathrm{Cu}$-oxide electrode with the oxidation temperature of $250^{\circ} \mathrm{C}$, however, $\mathrm{Cu}_{2} \mathrm{O}$ was oxidized to $\mathrm{CuO}$ (Fig. 3): the 

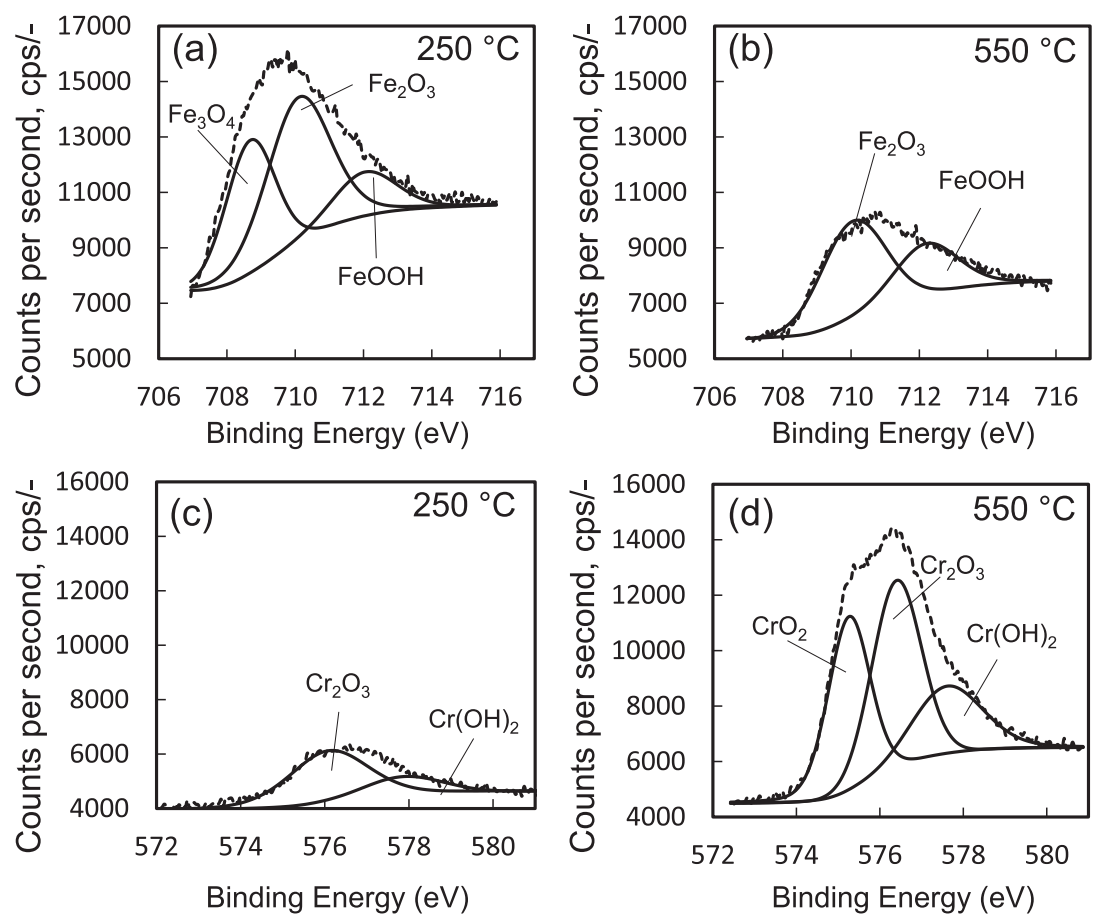

Fig. 13. XPS spectra of $\mathrm{Fe} 2 \mathrm{p}_{3 / 2}$ and $\mathrm{Cr} 2 \mathrm{p}_{3 / 2}$ of the passive film formed on Type 329J4L stainless steel with the oxidation temperatures of $250^{\circ} \mathrm{C}$ and $550^{\circ} \mathrm{C}$. (a)-(d) presents XPS spectra of (a) $\mathrm{Fe} 2 \mathrm{p}_{3 / 2}$ at $250^{\circ} \mathrm{C}$, (b) $\mathrm{Fe} 2 \mathrm{p}_{3 / 2}$ at $550^{\circ} \mathrm{C}$, (c) $\mathrm{Cr} 2 \mathrm{p}_{3 / 2}$ at $250^{\circ} \mathrm{C}$, and (d) $\mathrm{Cr} 2 \mathrm{p}_{3 / 2}$ at $550^{\circ} \mathrm{C}$, respectively.

photo-generated holes transferred into electrolyte, and the photo-generated holes oxidized $\mathrm{Cu}_{2} \mathrm{O}$ to $\mathrm{CuO}$. The oxides on the substrate effect on the film. Some photo-generated holes must transfer to the substrate side because the photo potential ennobled immediately upon light irradiation. It suggested that copper oxide substance except $\mathrm{Cu}_{2} \mathrm{O}$ is also included in the $\mathrm{Cu}$-oxide electrode with the oxidation temperature of $250{ }^{\circ} \mathrm{C}$. By double sweep cyclic voltammetry method (DSCV method), ${ }^{33,34)} \mathrm{CuO}$ and $\mathrm{Cu}(\mathrm{OH})_{2}$ in the $\mathrm{Cu}$-oxide film were actually detected. The $\mathrm{CuO}$ contributes the potential ennoblement immediately after light irradiation. In the $\mathrm{Cu}$-oxide electrodes with the oxidation temperatures of 450 and $550^{\circ} \mathrm{C}$, photo-corrosion occurred. Based on the oxidation reaction of photo-corrosion by photo-generated holes, ${ }^{35)}$ the surface decomposition of $\mathrm{CuO}$ can be expressed as Eq. (3):

$$
\mathrm{CuO}+2 \mathrm{~h}^{+} \rightarrow \mathrm{Cu}^{2+}+1 / 2 \mathrm{O}_{2}
$$

The photo-generated holes transferred into the electrolyte. In the $\mathrm{Cu}$-oxide electrode with the oxidation temperature of $350^{\circ} \mathrm{C}$, whose semiconductor property of the passive film is different with those with 450 and $550^{\circ} \mathrm{C}, \mathrm{CuO}$ did not decomposite. The band structure changes by the oxide thin-film on substrate. ${ }^{32)}$ The interactions between the $\mathrm{Cu}$-oxide film and the passive film of stainless steel substrate affected on potential and durability during the light irradiation. In present study, it is clarified made the existence of interaction between $\mathrm{Cu}$-oxide film and the passive film of stainless steel substrate clear, but an analysis of band structure diagram based on this experiment is necessary in the future. The photo-excited electrons may decompose $\mathrm{CuO}$ to $\mathrm{Cu}$.

$$
\mathrm{CuO}+2 \mathrm{H}^{+}+2 \mathrm{e}^{-} \rightarrow \mathrm{Cu}+\mathrm{H}_{2} \mathrm{O}
$$

The reaction in Eq. (4) was not occur because the behav- ior of electrode potential was stable in the electrode with the oxidation temperature of $350^{\circ} \mathrm{C}$. Therefore, the electrons oxidized water, and its surface reaction ${ }^{31)}$ can be expressed as:

$$
2 \mathrm{H}_{2} \mathrm{O}+2 \mathrm{e}^{-} \rightarrow \mathrm{H}_{2}+2 \mathrm{OH}^{-}
$$

The electrodes oxidized at $350^{\circ} \mathrm{C}$ exhibited the highest the durability because the photo-excited electrons and photo-generated holes hardly reacted with the substance of electrode surface by the interactions between the $\mathrm{Cu}$-oxide film and the passive film of stainless steel substrate.

\section{Conclusions}

We have produced $\mathrm{Cu}$-oxide electrodes by the hightemperature oxidation of pure $\mathrm{Cu}$ that was vacuum vapordeposited on stainless steel (Type 329J4L). The potentials and durability of these electrodes under light irradiation were evaluated, and the effect of electrode microstructure on the potential and durability were elucidated.

(1) The main phase of the vapor-deposited film on the electrodes with an oxidation temperature of $150^{\circ} \mathrm{C}$ was amorphous $\mathrm{Cu}$, the main phase at $250^{\circ} \mathrm{C}$ was $\mathrm{Cu}_{2} \mathrm{O}$, and that at 350,450 , and $550^{\circ} \mathrm{C}$ was $\mathrm{CuO}$.

(2) The passive film of the stainless steel substrates with the oxidation temperature between 150 and $350^{\circ} \mathrm{C}$ showed the n-type semiconductor property, instead those with the oxidation temperatures of 450 and $550^{\circ} \mathrm{C}$ were p-type semiconductor.

(3) In the electrodes oxidized at $250^{\circ} \mathrm{C}$, the potential became more ennobled with time as $\mathrm{Cu}_{2} \mathrm{O}$ was oxidized to form $\mathrm{CuO}$, although the potential ennobling immediately after light irradiation was relatively low.

(4) The potential of the electrodes with an oxidation temperature of $350^{\circ} \mathrm{C}$ stabilized with the highest ennoble- 
ment. The electrode surface morphology showed little change during the $24 \mathrm{~h}$ irradiation.

(5) Immediately after light irradiation, the potential of the electrodes with $\mathrm{CuO}$ was more ennobled compared to that of the electrodes with $\mathrm{Cu}_{2} \mathrm{O}$. Stronger potential ennobling was observed at higher oxidation temperatures. In the electrodes with an oxidation temperature of $450^{\circ} \mathrm{C}$ or higher, the potentials decreased immediately after irradiation due to the self-corrosion (photo-corrosion) of $\mathrm{CuO}$, and to the pitting corrosion of the stainless steel substrate with the passive film of p-type semiconductor.

(6) In the $\mathrm{Cu}$-oxide electrodes prepared at an oxidation temperature of $350^{\circ} \mathrm{C}$, the photo-excited electrons and photo-generated holes hardly reacted with the substance of electrode surface by the interactions between the $\mathrm{Cu}$-oxide film and the passive film of stainless steel substrate. The electrode exhibited the highest performance from the viewpoint of the potential and durability under light irradiation.

\section{Acknowledgements}

This work was financially supported by an ISIJ Research Promotion Grant, and an Ishihara and Asada Research Promotion Grant (The Iron and Steel Institute of Japan). Dr. Shigeyoshi Nakayama of Sumitomo Electric Industries, Limited, Analytical Characterization Center supported to use double sweep cyclic voltammetry to analyze the characterization of $\mathrm{Cu}$-oxide film. We would like to express our sincere gratitude to them.

\section{REFERENCES}

1) S. Motoda, S. Uematsu and T. Shinohara: ECS Trans., 41 (2012), 129.

2) S. Motoda, M. J. Strom and S. C. Dexter: ECS Trans., 16 (2009), 155.

3) S. Motoda, M. J. Strom and S. C. Dexter: ECS Trans., 25 (2010), 3.

4) S. Tamura, M. Morita, S. Motoda, S. Uematsu and T. Shinohara: ECS Trans., 58 (2014), 39.
5) T. J. Richadson, J. L. Slack and M. D. Rubin: Electrochimica Acta, 46 (2001), 228.

6) A. O. Musa, T. Akomolafe and M. J. Carter: Sol. Energy Mater. Sol. Cells, 51 (1998), 305.

7) M. R. Johan, M. S. M. Suan, N. L. Hawari and H. A. Ching: Int. J. Electrochem. Sci., 6 (2011), 6094.

8) H. Nakajima, M. Masui, F. Kaneko, T. Wada and M. Takeuchi: $J$. Surf. Finish. Soc. Jpn., 45 (1994), 1260.

9) T. Imura: J. Met. Finish. Soc. Jpn., 32 (1981), 592

10) J. Kramer: Ann. Phys., 19 (1934), 37.

11) K. Tsukimura: Chishitsu News, (1995), No. 496, 19.

12) T. Notoya: Pip. Eng., 5 (2004), 1.

13) H. H. Uhlig and R. W. Revie: Corrosion and Corrosion Control, John Wiley \& Sons, New York, (1985), 33.

14) D. D. Hawn and B. M. DeKoven: Surf. Interface Anal., 10 (1987), 63

15) S. L. T. Andersson and R. F. Howe: J. Phys. Chem., 93 (1989), 4913.

16) R. V. Siriwardene and J. M. Cook: J. Colloid Interface Sci., 108 (1985), 414

17) P. Mills and J. L. Sullivan: J. Phys. D, 16 (1983), 723.

18) D. Brion: Appl. Surf. Sci., 5 (1980), 133.

19) G. C. Allen, M. T. Curtis, A. J. Hooper and P. M. Tucker: J. Chem. Soc., Dalton Trans., 14 (1974), 1525.

20) E. Paparazzo: J. Electron Spectrosc. Relat. Phenom., 43 (1987), 97.

21) D. Shuttleworth: J. Phys. Chem., 84 (1980), 1629.

22) O. Nishimura, K. Yabe and M. Iwaki: J. Electron Spectrosc. Relat. Phenom., 49 (1989), 335.

$23)$ B. Wichterlova, L. Krajcikova, Z. Tvaruskova and S. Beran: J. Chem. Soc. Faraday Trans., 80 (1984), 2639.

24) C. Sleigh, A. P. Pijpers, A. Jaspers, B. Coussens and R. J. Meier: J. Electron Spectrosc. Relat. Phenom., 77 (1996), 41.

$25)$ G. C. Allen, S. J. Harris, J. A. Jutson and J. M. Dyke: Appl. Surf. Sci., 37 (1989), 111.

26) S. Mischler, H. J. Mathieu and D. Landolt: Surf. Interface Anal., 11 (1988), 182.

27) T. P. Moffat, R. M. Latanision and R. R. Ruf: Electrochim. Acta, 40 (1995), 1723.

28) M. G. S. Ferreira, M. D. C. Belo, N. E. Hakiki, G. Goodlet, M. F. Montemor and A. M. P. Simoes: J. Braz. Chem. Soc., 13 (2002), 433.

29) J. Liu, S. Yang, W. Wu, Q. Tian, S. Cui, Z. Dai, F. Ren, X. Xiao and C. Jiang: ACS Sustain. Chem. Eng., 3 (2015), 2975.

30) M. T. Greiner, M. G. Helander, W. M. Tang, Z. B. Wang, J. Qiu and Z. H. Lu: Nat. Mater., 11 (2012), 76.

31) N. Sato: Tetsu-to-Hagané, 76 (1990), 1423.

32) W. Siripala: Trends in Solar Energy Research, ed. by T. P. Hough, Nova Science Publishers, New York, (2006), 1.

33) S. Nakayama, A. Kimura, M. Shibata, S. Kuwabata and T. Osakai: J. Electrochem. Soc., 148 (2001), B467.

34) S. Nakayama, T. Notoya and T. Osakai: Anal. Sci., 28 (2012), 323.

35) Y. Aikawa: Zairyo-to-Kankyo, 41 (1992), 111. 